\title{
IMPACT OF CUTTING ELEMENTS ON FORCES AND ROUGHNESS OF SURFACE DURING TURNING HARD STEEL X160 CrMo V12 WITH CBN TOOL
}

\author{
Sreten Savićević, Milan Vukćević, Sergey A. Klimenko, Ljubodrag Tanović
}

Original scientific paper

The goal of these researches is related to the analyses of the impact of elements of cutting mode on the change of cutting forces, quality of a machined surface and change of physical and mechanical properties of a surface layer of a CBN tool for turning of X160 CrMo V12 steel having a hardness of $60 \pm 2$ HRC. The results of the analyses of tool surface wear indicate the presence of oxidation and changes of physical and mechanical properties in a tool surface layer. The evaluation clearly shows that a radial force $\left(F_{\mathrm{r}}\right)$ is dominant during the machining of this steel. The mathematical models of dependence of cutting force and a quality of machined surface were developed. It was ascertained that an oxidation of the tool surface, next to a contact zone toolcutting chip, leads to the increase of their hardness and reduction of their strength, and it finally leads to the emergence of micro-wear of a cutting knife and rapid tool wear.

Keywords: $C B N$ (corundum and boron-nitride); force; roughness; turning; wear

\section{Utjecaj parametara rezanja na sile i hrapavost površine pri tokarenju kaljenog čelika X160 CrMo V12 alatom od CBN}

Izvorni znanstveni članak

Cilj ovih istraživanja se odnosi na istraživanje uticaja elemenata režima rezanja na promenu sila rezanja, kvaliteta obrađene površine i promene fizičko-

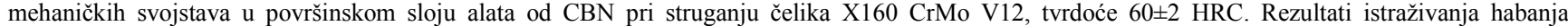
površine alata ukazuju na prisustvo procesa oksidacije i promene fizičko-mehaničkih svojstava u površinskom sloju alata. Evaluacija sile jasno pokazuje da je radijalna sila $\left(F_{\mathrm{r}}\right)$ dominantna pri obradi ovog čelika. Razvijeni su matematički modeli zavisnosti sila rezanja i kvaliteta obrađene površine. Utvrđeno je da oksidacija površine alata, neposredno uz kontaktnu zonu alat-strugotina, dovodi do povećanja njihove tvrdoće i smanjenja čvrstoće, što u krajnjoj meri dovodi do pojave mikrokrzanja reznog sečiva a time i ubrzanog habanja alata

Ključne riječi: $C B N$; habanje; hrapavost; sila; tokarenje

\section{Introduction}

The machining of superhard materials demands the use of a cutting tool that will satisfy the needed conditions from the aspect of the processes emerging during a cutting. There are many sources comprising the researches related to the use of superhard materials (SHM) in the machining of high-hardness materials $[1,2]$. Thence, the authors $[3 \div 5]$ in their researches analyse the impact of a composition, hardness of tool and workpiece, as well as the elements of machining mode on the tool consistency and quality of the processed surface. Paper [6] is focused on the research problems related to the surface integrity of the machined surface from the point of application of tools coated with $\mathrm{Al}_{2} \mathrm{O}_{3}$, and the appearance of plasticization and the material flow in the processing zone, at different cutting speeds.

The authors $[7,8]$, analyse the impact of wear on the change of CBN tool geometry, especially the impact of a crater on lead surface of a tool. Regarding the CBN tool wear, three basic mechanisms can be mentioned: 1) chemical wear conditioned by interacting with workpiece material and oxidation; 2) formation of coating on the tool surface for high temperatures and 3) abrasive wear $[9 \div 12]$.

Very interesting research is present in the domain of designing new structures of cutting tools for turning relative to the existing commercial ones. So authors [13], investigate the influence, of the position of the cutting edges and the tool tip on the surface roughness and the necessary energy cutting. The aim is to design tools of optimal geometry from the point of transition from the forehead to the cylindrical surface of the workpiece.
Many researchers analysed the impact of elements of cutting mode on cutting forces and surface roughness and the results indicate a dominant impact of a radial component of cutting force for the interval of cutting depth that is smaller than the radius of round tip of the tool $[14 \div 17]$. At the same time, they noticed the presence of smaller cutting forces during bigger cutting speeds as a consequence of thermal softening of the workpiece, namely the temperature rise.

A part of the researches is related to the contemporary methods for optimization of machining with tools based on PCBN $[18,19]$.

The main wear mechanism of $\mathrm{CBN}$ during the machining of steel emerges as a consequence of abrasion of hard carbide particles present in the workpiece $[20 \div 22]$. Many researchers compared hard metal and $\mathrm{CBN}$ during the processing of super hard steel and found that the cutting temperature for $\mathrm{CBN}$ tools is lower than for hard metal for the same machining conditions [23].

The state of the surface layer of cutting tool is mainly conditioned by actions of heat generated in the cutting zone. For the purposes of an increase of tool consistency, it is necessary to determine the border of the heat impact zone, where the phenomena related to the changes of chemical composition and mechanical characteristics of tool surface material layer can emerge as a consequence of oxidation.

These processes are expressed during the machining of steel and high strength alloys with CBN tools because the temperatures up to $1200{ }^{\circ} \mathrm{C}$ emerge in the cutting zone since the machining is executed without cooling [24]. A very significant aspect connected to the tool wear is related to the change of chemical composition and mechanical properties. A large number of works is 
devoted to the research of influence, the application of coolant, on the indicators of the quality of processing, from the aspect of cooling and the emulsion composition. Authors $[25,26]$, in their research came to the conclusion that in the processing of steel X10CrNi18-8 with cooling emulsion in the form of fog, reduced surface roughness is compared to the air under pressure cooling or treatment without cooling. This is explained in that way, the treated surface to form a chemical compound and of the active substance of the modifier, and as a barrier layer a positive effect on the cutting conditions and the reduction of friction.

Depending on the composition, various composites start interacting with oxygen leading to chemical processes. The experimental researches in the area of oxidation of PSTM based on $\mathrm{CBN}$-ciborit show that the oxidation emerges at $800{ }^{\circ} \mathrm{C}$. Further temperature rise leads to an intensive oxidation of material, evaporation of boron oxide and removal of free nitrogen.

This paper presents the results of the experimental researches of the impact of cutting conditions on the cutting forces and roughness of machined surface of X160CrMo V12 steel, with a particular emphasis on the changes of composition of the surface layer of CBNciborit.

\section{Conditions for conducting experiments}

The machining centre HMC 500/40 (Fig. 1), $15 \mathrm{~kW}$ power, main axle rotation up to $6000 \mathrm{rpm}$ and tool of PCBN-ciborit (Institute of superhard materials, Kiev, UA) was used for the experiments. A two - component dynamometer Kistler 5007, cDAQ-9174 NI was used for the measurement of forces. Software for data acquisition LabWiew and Matlab, as well as a laser microscope LSM 510 , and the device for measurement of the roughness Time TR200 were used.

The machined material is made of high-alloyed steel (X160 CrMo V12, produced by Bohler K105, W.Nr.1.2601) with high chrome content and dedicated for making of tools used in pharmaceutical industry. Tab. 1 gives the chemical composition and hardness of material.

Two types were used: CBN-ciborit, label CCGW $09 \mathrm{~T} 304\left(\alpha=7^{\circ}, \gamma=0^{\circ}\right)$ and CCGW120404 $\left(\alpha=6^{\circ}, \gamma=-6^{\circ}\right)$ whereby the elements of the machining mode are given in Tab. 2.

A triple-factor orthogonal plan of the first row with a shape of $2 K(K=3, v, f, a)$ was adopted for the plan of the experiment.

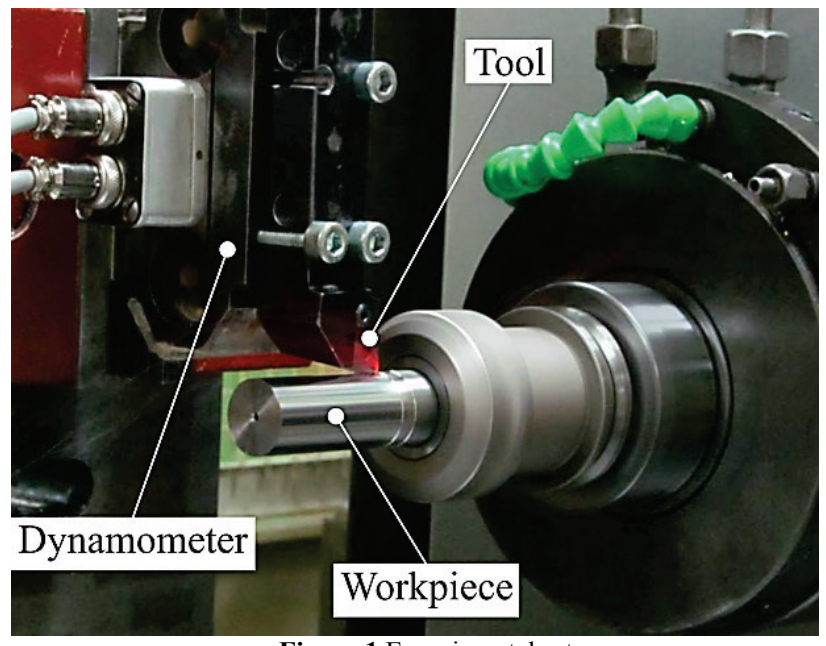

Figure 1 Experimental set-up

Table 1 Chemical composition of hardened steel X160 CrMo V12

\begin{tabular}{|c|c|}
\hline No. of batch & $A=3278$ \\
\hline$\% \mathrm{C}$ & 1,63 \\
\hline$\% \mathrm{Si}$ & 0,36 \\
\hline$\% \mathrm{Mn}$ & 0,36 \\
\hline$\% \mathrm{P}$ & 0,024 \\
\hline$\% \mathrm{~S}$ & 0,0012 \\
\hline$\% \mathrm{Cr}$ & 11,64 \\
\hline$\% \mathrm{Mo}$ & 0,54 \\
\hline$\% \mathrm{~V}$ & 0,29 \\
\hline$\% \mathrm{~W}$ & 0,48 \\
\hline Note: Material hardness $60 \pm 2 \mathrm{HRC}$ & \\
\hline
\end{tabular}

Table 2 Elements of a machining mode

\begin{tabular}{|l|c|c|c|}
\hline \multicolumn{1}{|c|}{ Level } & Low & Medium & High \\
\hline Cutting speed $v / \mathrm{m} / \mathrm{min}$ & 135 & 155 & 180 \\
\hline Feed $f / \mathrm{mm} / \mathrm{rev}$ & 0,05 & 0,10 & 0,20 \\
\hline Depth of cut $a / \mathrm{mm}$ & 0,05 & 0,10 & 0,20 \\
\hline
\end{tabular}

Table 3 Experimental results

\begin{tabular}{|c|c|c|c|c|c|c|c|c|}
\hline \multirow{2}{*}{\multicolumn{3}{|c|}{$\frac{\text { Plan of matrices of experiments }}{\text { Cutting condition }}$}} & \multicolumn{6}{|c|}{ Results } \\
\hline & & & \multicolumn{3}{|c|}{$\gamma=0^{\circ}$} & \multicolumn{3}{|c|}{$\gamma=-6^{\circ}$} \\
\hline$v / \mathrm{m} / \mathrm{min}$ & $a / \mathrm{mm}$ & $\mathrm{f} / \mathrm{mm} / \mathrm{rev}$ & $F_{\mathrm{t}} / \mathrm{N}$ & $F_{\mathrm{r}} / \mathrm{N}$ & $R a / \mu \mathrm{m}$ & $F_{\mathrm{t}} / \mathrm{N}$ & $F_{\mathrm{r}} / \mathrm{N}$ & $R a / \mu \mathrm{m}$ \\
\hline 180 & 0,20 & 0,20 & 138,1 & 109,4 & 1,524 & 154,2 & 156,7 & 2,149 \\
\hline 135 & 0,20 & 0,20 & 142,8 & 115,1 & 1,410 & 164,1 & 168,3 & 1,853 \\
\hline 180 & 0,05 & 0,20 & 51,4 & 61,4 & 1,730 & 61,1 & 84,7 & 1,932 \\
\hline 180 & 0,20 & 0,05 & 56,0 & 64,5 & 0,582 & 64,1 & 78,1 & 0,648 \\
\hline 155 & 0,10 & 0,10 & 50,4 & 69,5 & 0,654 & 59,4 & 78,3 & 0,732 \\
\hline 135 & 0,20 & 0,05 & 63,8 & 65,2 & 0,431 & 68,3 & 77,6 & 0,429 \\
\hline 180 & 0,05 & 0,05 & 24,4 & 37,8 & 0,573 & 24,8 & 37,5 & 0,719 \\
\hline 155 & 0,10 & 0,10 & 54,0 & 71,1 & 0,578 & 60,3 & 74,1 & 0,732 \\
\hline 135 & 0,05 & 0,05 & 23,3 & 35,9 & 0,474 & 24,6 & 39,4 & 0,557 \\
\hline 155 & 0,10 & 0,10 & 55,7 & 64,2 & 0,578 & 57,9 & 68,5 & 0,728 \\
\hline 155 & 0,10 & 0,10 & 54,0 & 61,7 & 0,761 & 56,7 & 61,9 & 0,728 \\
\hline 135 & 0,05 & 0,20 & 53,6 & 72,4 & 1,339 & 56,9 & 81,6 & 1,367 \\
\hline
\end{tabular}




\section{Results and discussion}

Tab. 3 presents the measured results, medium values of ten repeated measurements having the deflections up to $5 \%$. Based on the experimental results, using a regression and dispersion analysis, the mathematical models were obtained $(1,2)$. tool.

For machining with a CCGW 09T304 $\left(\alpha=7^{\circ}, \gamma=0^{\circ}\right)$

$$
\begin{aligned}
& F_{\mathrm{t}}=2089,053 \cdot v^{-0,135} \cdot a^{0,686} \cdot f^{0,592} \\
& F_{\mathrm{r}}=894,951 \cdot v^{-0,151} \cdot a^{0,392} \cdot f^{0,412} \\
& R a=0,118 \cdot v^{0,716} \cdot a^{-0,028} \cdot f^{0,774}
\end{aligned}
$$

For machining with a CCGW120404 $\left(\alpha=6^{\circ}, \gamma=-6^{\circ}\right)$ tool.

$$
\begin{aligned}
& F_{\mathrm{t}}=1664,725 \cdot v^{-0,042} \cdot a^{0,713} \cdot f^{0,630} \\
& F_{\mathrm{r}}=1181,584 \cdot v^{-0,068} \cdot a^{0,496} \cdot f^{0,544} \\
& R a=0,038 \cdot v^{1,009} \cdot a^{0,008} \cdot f^{0,820}
\end{aligned}
$$

Based on the mathematical models $(1,2)$, Figs. $2 \div 4$ present the diagrams of changes of components of forces $F_{\mathrm{r}}, F_{\mathrm{t}}$ and roughness $R a$.

\subsection{Impact of lead angle}

The lead angle of a tool $(\gamma)$ impacts on the compression of chips and has no direct impact on the roughness of machined surface. Indirectly, a rise of lead angle facilitates the removal of chips, reduces both the elastic deformations of the machined surface and roughness. By a change of the lead angle from $\gamma=0^{\circ}$ to $\gamma=6^{\circ}$, radial force $\left(F_{\mathrm{r}}\right)$ rises to $45 \%$, namely tangential force $\left(F_{\mathrm{t}}\right)$ to $12 \%$ in the observed range of the research.

\subsection{Impact of cutting parameters on cutting forces and surface roughness}

The cutting depth has the strongest impact on the change of a component of cutting force $F_{\mathrm{r}}$, while a step has the strongest impact on both tools on the $F_{t}$. The variations of cutting forces range in the interval of $F_{\mathrm{t}}=2,1 \div 2,7$ and $F_{\mathrm{r}}=1,6 \div 2,3\left(\gamma=0^{\circ}\right)$, namely $F_{\mathrm{t}}=2,4 \div 2,8$ and $F_{\mathrm{r}}=1,8 \div 2,1\left(\gamma=-6^{\circ}\right)$. With an increase of the cutting speed both components decrease as a consequence of an increased heating and softening of processed material. For both tools, a component of $F_{\mathrm{r}}$ force, in a range of the change of machining mode, is bigger than $F_{\mathrm{t}}$. The graph in Fig. 4 presents the change of the surface roughness where the rise of roughness with the rise of cutting depth in the entire range of cutting can be observed. For smaller cutting depths, a relatively high roughness is present as the consequence of a scratching - ploughing instead of a cutting. With the rise of the depth, the ploughing effect is reduced and the better quality of surface is achieved in that way.

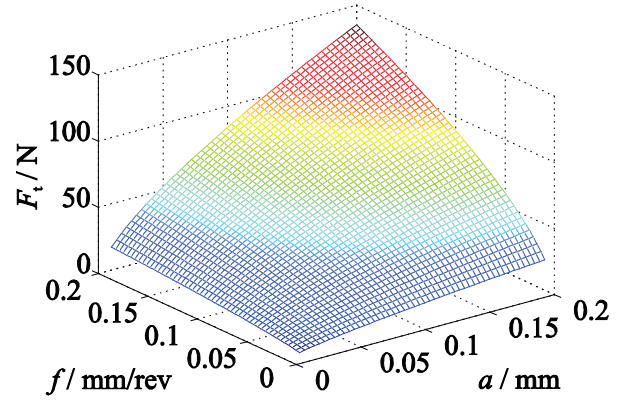

a)

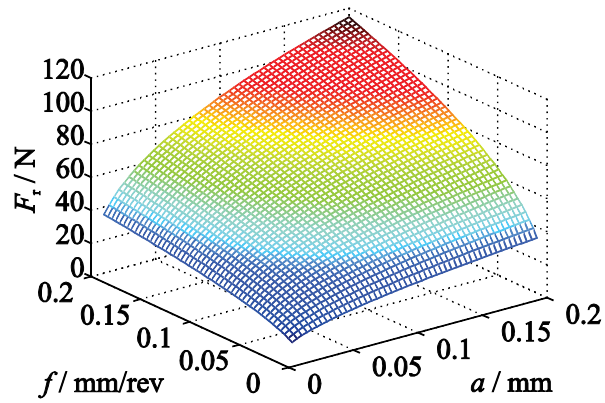

b)

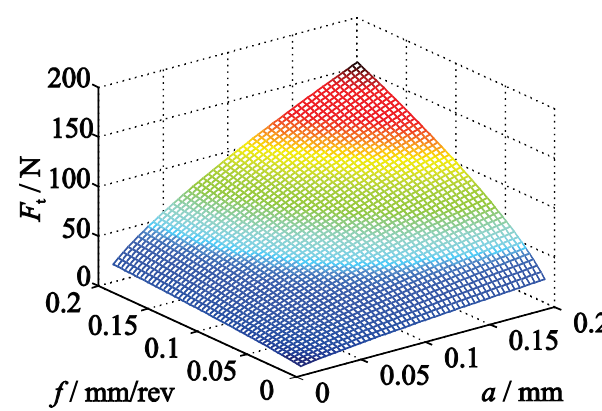

a)

Figure 3 Variation of cutting force $\left.F_{\mathrm{t}} \mathrm{a}\right)$ and b) $F_{\mathrm{r}}\left(\gamma=-6^{\circ}, v=155 \mathrm{~m} / \mathrm{min}\right)$ 


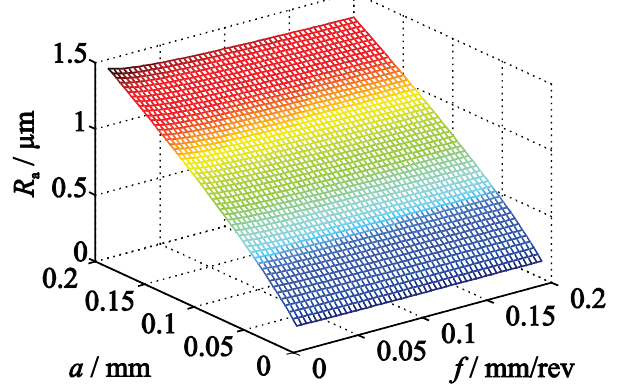

a)

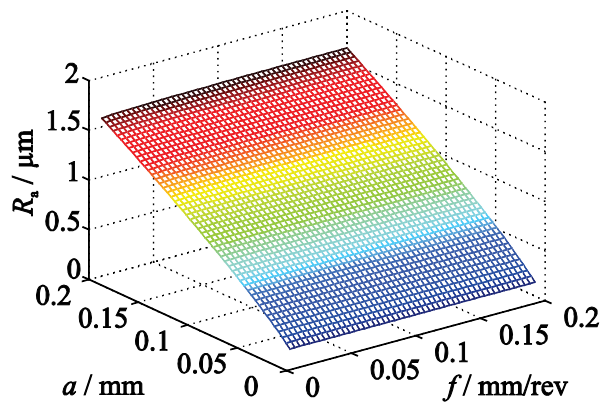

b)

Figure 4 Variation in surface roughness, $v=155 \mathrm{~m} / \mathrm{min}(\mathrm{a}) \gamma=0^{\circ}$, b) $\gamma=-6^{\circ}$ )

\subsection{Tool wear}

Fig. 5 presents the contact surfaces of the cutting tool after the machining of hard steel X160 CrMo V12. For a Ciborit tool $\left(\gamma=0^{\circ}\right)$, there is a region with brittle destruction on the back surface (Fig. 5a) indicating the bigger strain of lead tool surface and an insufficient strength of the composite in case of the exploitation in the conditions of high temperatures. The destruction of the cutting tool during the machining with speed of $v=135$ $\mathrm{m} / \mathrm{min}(a=0,2 \mathrm{~mm})$ emerged after $1,66 \mathrm{~min}$. At a part of the lead tool surface, the layer of machined material that was pasted as a result of adhesion in the cutting zone can be observed (Fig. 5b). Based on the shape of the contact on the lead tool surface, it is possible to draw a conclusion about a significant impact of the mechanism of abrasive adhesion wear on the cutting speed of the tool.

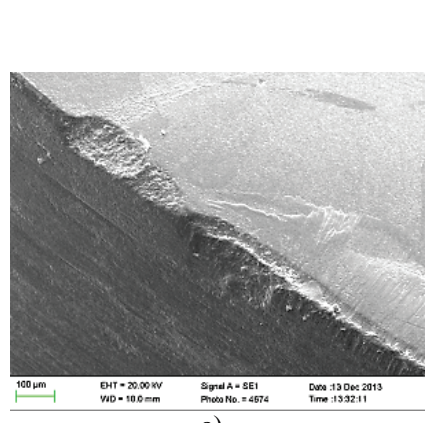

a)

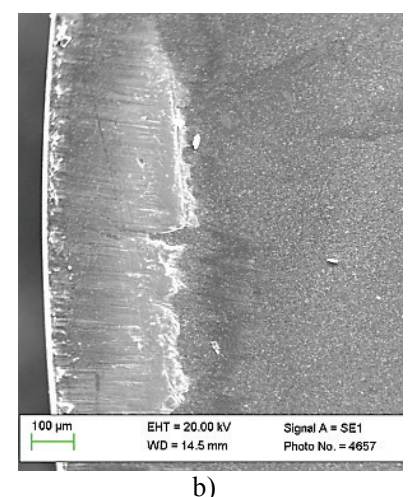

b)

Figure 5 Tool contact surface after machining $(v=135 \mathrm{~m} / \mathrm{min}, a=0,2 \mathrm{~mm}, f=0,2 \mathrm{~mm} / \mathrm{rev})$

Table 4 Chemical composition (\%) of Ciborit thorax tool surface

\begin{tabular}{|c|c|c|c|c|c|c|c|}
\hline $\begin{array}{c}\text { Contact } \\
\text { zone }\end{array}$ & $\mathrm{B}$ & $\mathrm{C}$ & $\mathrm{N}$ & $\mathrm{O}$ & $\mathrm{Si}$ & $\mathrm{Ti}$ & $\mathrm{Fe}$ \\
\hline 1 & 9,07 & 20,57 & 10,44 & 7,71 & 10,14 & 11,72 & 4,69 \\
\hline 2 & 6,53 & 10,37 & 7,18 & 3,29 & 9,85 & 8,20 & 7,74 \\
\hline 3 & 2,49 & 8,08 & 0,00 & 0,86 & 0,61 & 1,08 & 2,18 \\
\hline 4 & 8,87 & 14,54 & 11,64 & 3,75 & 4,24 & 3,57 & 3,36 \\
\hline 5 & 25,31 & 4,93 & 33,64 & 8,12 & 15,29 & 8,58 & 1,40 \\
\hline 6 & 19,92 & 3,94 & 31,80 & 12,33 & 18,99 & 8,55 & 1,75 \\
\hline 7 & 24,99 & 4,68 & 35,30 & 8,66 & 14,55 & 7,98 & 1,93 \\
\hline 8 & 26,15 & 4,95 & 36,47 & 5,21 & 14,69 & 8,44 & 3,33 \\
\hline 9 & 25,22 & 5,41 & 37,77 & 4,34 & 13,78 & 8,56 & 4,07 \\
\hline 10 & 24,18 & 5,01 & 36,72 & 4,75 & 14,37 & 8,59 & 5,41 \\
\hline 11 & 27,53 & 5,00 & 37,23 & 4,90 & 13,38 & 8,16 & 2,98 \\
\hline 12 & 21,75 & 13,05 & 37,70 & 4,96 & 12,14 & 7,75 & 2,14 \\
\hline
\end{tabular}

The chemical composition of the tool surface was determined by the method of micro x-ray spectroscopy analysis. Fig. 6 presents the position of measurement zones at the lead tool surface where the chemical composition was determined and is given in Tab. 4. The increased content of steel and oxygen on the tool surface is related to the gluing of particles of the machined material and products of interactions of contact materials.

Based on the data from Tab. 4 and Fig. 6, a diagram of distribution of oxygen on the lead tool surface of Ciborit, in the direction perpendicular to the main knife, (Fig. 7) was formed.

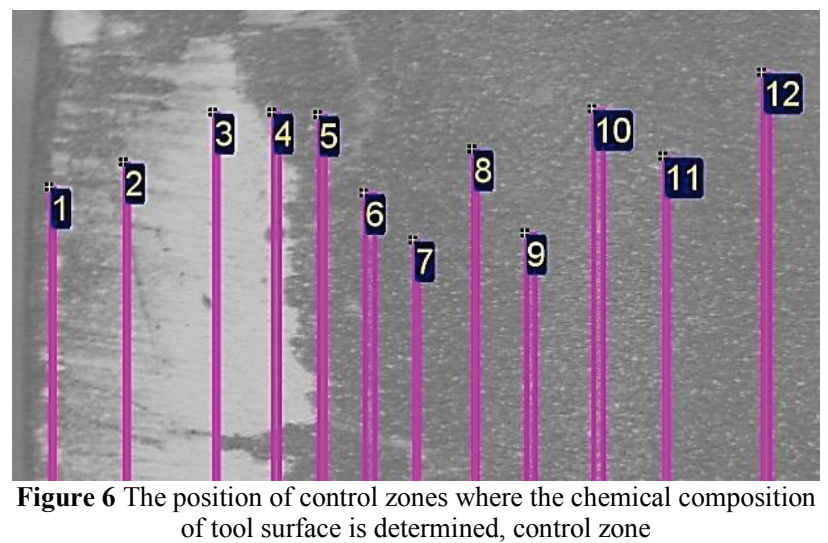

A low content of oxygen was observed at the distance of $X=180 \div 200 \mu \mathrm{m}$ from the cutting knife.

In cases of the contact of chips with the lead tool surface at a length of $120 \mu \mathrm{m}$, the effect of insulation of this area from the external surroundings occurs as well as the oxygen rise at the distance of $X=300 \div 600 \mu \mathrm{m}$ from the cutting knife. This effect can be explained by the fact that this area is situated in the interactions with air. Additionally, a liquid phase of product of interactions of contact material that also contains oxygen is fed into this zone.

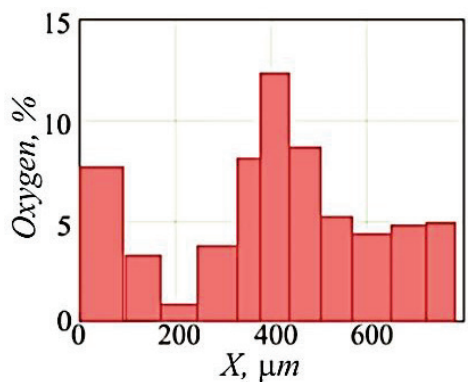

Figure 7 Diagram of oxygen distribution on Ciborit thorax tool surface (\%) 


\section{Conclusion}

During the machining of hard steel X160 CrMo V12 with CBN-Ciborit tool, the depth of cut has the biggest impact on a radial cutting force $F_{\mathrm{r}}$, followed by a step, while a step followed by depth of cut has the biggest impact on a tangential cutting force. The same trend is represented also for tools with lead angles $\gamma=0^{\circ}$ and $\gamma=-6^{\circ}$. For the machining by the tool with $\gamma=0^{\circ}$, a lower roughness of the machined surface and more favourable removal of chips are achieved. Both components of forces are reduced by an increase of the cutting speed as the consequence of heating and softening of material.

For the machining by the $\gamma=-6^{\circ}$ tool, by an increasing of a step of $f=0,05 \div 0,2 \mathrm{~mm} / \mathrm{rev}$, the rise of forces is almost identical for both depths of cut and is $F_{\mathrm{t}}$ for 2,46, $F_{\mathrm{r}}$ for 2,25 times $(v=180 \mathrm{~m} / \mathrm{min}, a=0,05 \mathrm{~mm})$, namely $F_{\mathrm{t}}$ for 2,31, $F_{\mathrm{r}}$ for 2,07 times $(v=135 \mathrm{~m} / \mathrm{min}, a=0,05 \mathrm{~mm})$. For a depth of cut of $a=0,2 \mathrm{~mm}$, with an increase of a step of $f=0,05 \div 0,2 \mathrm{~mm} / \mathrm{rev}$, a rise of forces is present, $F_{\mathrm{t}}$ for $2,4, F_{\mathrm{r}}$ for 2 times $(v=180 \mathrm{~m} / \mathrm{min})$, namely $F_{\mathrm{t}}$ for $2,40, F_{\mathrm{r}}$ for 2,16 times $(v=135 \mathrm{~m} / \mathrm{min})$.

The significant oxygen content in the tool surface is observed by the analysis of the chemical composition and it has the biggest value outside the contact zone at the distance of $0.5 \mathrm{~mm}$ from the knife. At the same time, the change of physical and mechanical properties on the tool surface leads to its rapid wear. For the evaluation process of the structural composition and mechanical properties of a CBN - based tool surface layer the following assumption can be applied: Oxidation of tool surface immediately to the contact zone tool-chip leads to the rise of its hardness and reduction of stiffness, that finally leads to the emergence of micro sliding of the tool composite as well as the rapid wear.

\section{References}

[1] Senthilkumar, N.; Tamizharasan, T.; Anandakrishnan, V. An ANN approach for predicting the cutting inserts performances of different geometries in hard turning. // Advances in Production Engineering \& Management. 8, 4(2013), pp. 231-241. https://doi.org/10.14743/apem2013.4.170.

[2] Natasha, A. R.; Ghani, J. A.; Che Haron, C. H.; Syarif, J.; Musfirah, A. H. Temperature at the Tool Chip Interface in Cryogenic and Dry Turning of AISI 4340 Using Carbide Tool. // International Journal of Simulation Modelling. 15, 2(2016), pp. 201-212. https://doi.org/10.2507/IJSIMM15(2)1.314

[3] Angseryd, J.; Coronel, E.; Elfwing, M.; Olsson, E.; Andren, H. O. The microstructure of the affected zone of a worn PCBN cutting tool characterised with SEM and TEM. // Wear. 267, 5-8(2009), pp. 1031-1040. https://doi.org/10.1016/j.wear.2008.12.075

[4] Poulachon, G.; Bandyopadhyay, B. P.; Jawahir, I. S.; Pheulpin, S.; Seguin, E. Wear behavior of CBN tools while turning various hardened steels. // Wear. 256, 3-4(2004), pp. 302-310. https://doi.org/10.1016/s0043-1648(03)00414-9

[5] Enomoto, S.; Kato, M.; Miyazawa, S.; Ono, T. Characteristics of tool life of CBN cutting tool in turning chromium-molyb-denum steels of various hardness. // Bulletin of the Japan Society of Precision Engineering. 21, 3(1987), pp. 209-210.

[6] Krolczyk, G.; Nieslony, P.; Legutko, S.; Hloch, S.; Samardzic, I. Investigation of Selected Surface Integrity
Features of Duplex Stainless (DSS) After Turning. // Metalurgija. 54, 1 (2015), pp. 91-94.

[7] Huang, Y.; Liang, S. Y. Modeling of CBN tool crater wear in finish hard turning. // The International Journal of Advanced Manufacturing Technology. 24, 9-10(2004), pp. 632-639.

[8] Huang, Y.; Dawson, T. G. Tool crater wear depth modeling in CBN hard turning. // Wear. 258, 9(2005), pp. 1455-1461. https://doi.org/10.1016/j.wear.2004.08.010

[9] Zhou, J. M.; Andersson, M.; Stahl, J. E. The monitoring of flank wear on the $\mathrm{CBN}$ tool in the hard turning process. //The International Journal of Advanced Manufacturing Technology. 22, 9-10(2003), pp. 697-702. https://doi.org/10.1007/s00170-003-1569-2

[10] Lin, H. M.; Liao, Y. S.; Wei, C. C. Wear behavior in turning high hardness alloy steel by CBN tool. // Wear. 264, 7(2008), pp. 679-684. https://doi.org/10.1016/j.wear.2007.06.006

[11] Bouacha, K.; Yallese, M. A.; Mabrouki, T.; Rigal, J. F. Statistical analysis of surface roughness and cutting forces using response surface methodology in hard turning of AISI 52100 bearing steel with CBN tool. // International Journal of Refractory Metals and Hard Materials. 28, 3(2010), pp. 349-361. https://doi.org/10.1016/j.jjrmhm.2009.11.011

[12] Lalwani, D. I.; Mehta, N. K.; Jain, P. K. Experimental investigations of cutting parameters influence on cutting forces and surface roughness in finish hard turning of MDN250 steel. // Journal of materials processing technology. 206, 1(2008), pp. 167-179. https://doi.org/10.1016/j.jmatprotec.2007.12.018

[13] Monka, P.; Monkova, K.; Balara, M.; Hloch, S.; Rehor, J.; Andrej, A.; Somsak, M. Design and experimental study of turning tools with linear cutting edges and comparison to commercial tools. // The International Journal of Advanced Manufacturing Technology. 85, 9(2016), pp. 2325-2343. https://doi.org/10.1007/s00170-015-8065-3

[14] Huang, Y.; Liang, S. Y. Modeling of cutting forces under hard turning conditions considering tool wear effect. // Journal of manufacturing science and engineering. 127, 2(2005), pp. 262-270. https://doi.org/10.1115/1.1852571

[15] Yallese, M. A.; Chaoui, K.; Zeghib, N.; Boulanouar, L.; Rigal, J. F. Hard machining of hardened bearing steel using cubic boron nitride tool. // Journal of Materials Processing Technology. 209, 2(2009), pp. 1092-1104. https://doi.org/10.1016/j.jmatprotec.2008.03.014

[16] Karpat, Y.; Özel, T. 3-D FEA of hard turning: investigation of PCBN cutting tool micro-geometry effects. // Transactions of NAMRI/SME. 35(2007), pp. 1-8.

[17] Fnides, B.; Aouici, H.; Yallese, M. A. Cutting forces and surface roughness in hard turning of hot work steel X38CrMoV5-1 using mixed ceramic. // Mechanics. 70, 2(2008), pp. 73-78.

[18] Jurkovic, Z.; Cukor, G.; Andrejcak, I. Improving the surface roughness at longitudinal turning using the different optimization methods. // Technical Gazette. 17, 4(2010), pp. 397-402.

[19] Puh, F.; Šegota, T.; Jurković, Z. Optimization of hard turning process parameters with PCBN tool based on the Taguchi method. // Technical Gazette. 19, 2(2012), pp. 415419.

[20] Nakayama, K.; Arai, M.; Kanda, T. Machining characteristics of hard materials. // CIRP AnnalsManufacturing Technology. 37, 1(1988), pp. 89-92.

[21] Ohtani, T.; Yokogawa, H. The effects of workpiece hardness on tool wear characteristics. Machining of cold work tool steel with $\mathrm{CBN}$, ceramic and carbide tools. // Bulletin of the Japan Society of Precision Engineering. 22, 3(1988), pp. 229-231.

[22] Tanovic, L.; Bojanic, P.; Puzovic, R.; Klimenko, S. Polycrystalline Cubic Boron Nitride (PCBN) Tool Life and 
Wear in Turning of Amorphous-Crystalline Iron-Based Coatings. // Strojniški vestnik-Journal of Mechanical Engineering. 57, 12(2011), pp. 904-910. https://doi.org/10.5545/sv-jme.2011.010

[23] Narutaki, N.; Yamane, Y.; Okushima, K. Tool wear and cutting temperature of CBN tools in machining of hardened steels. // Ann. CIRP. 28, 1(1979), pp. 23-28.

[24] Новиков, Н. В. Сверхтвердые материалы. Получение и применение - Обработка материалов лезвийным инструментом. ИСМ им. В. Н. Бакуля, Киев, 2006.

[25] Maruda, W. R.; Feldshtein, E.; Legutko, S.; Krolczyk, M. $\mathrm{G}$. Research on emulsion mist generation in the conditions of minimum quantity cooling lubrication (MQCL). // Technical Gazette. 22, 5(2016), pp. 1213-1218.

[26] Maruda, W. R.; Legutko, S.; Krolczyk, M. G.; Hloch, S.; Michalski, M.; An influence of active additives on the formation of selected indicators of the condition of the $\mathrm{X} 10 \mathrm{CrNi18-8}$ stainless steel surface layer in MQCL conditions. // International Journal of Surface Science and Engineering. 9, 5(2015), pp. 452-465.

https://doi.org/10.1504/IJSURFSE.2015.072069

\section{Authors' addresses}

Prof. dr Sreten Savićević

University of Montenegro, Faculty of Mechanical Engineering, Džordža Vašingtona bb, 81000 Podgorica, Montenegro

E-mail: sreto@ac.me

\section{Prof. dr Milan Vukćević}

University of Montenegro, Faculty of Mechanical Engineering, Džordža Vašingtona bb, 81000 Podgorica, Montenegro

E-mail: milanvu@ac.me

\section{Prof. dr Sergey A. Klimenko}

V. Bakul Institute for Superhard Materials of the National, Academy of Sciences of Ukraine,

Avtozavodskaya Str., 04074 Kiev, Ukraine

E-mail: atmu@ism.kiev.ua

\section{Prof. dr Ljubodrag Tanović}

University of Belgrade, Faculty of Mechanical Engineering,

Kraljice Marije 16, 11120 Belgrade 35, Serbia

E-mail: 1tanovic@mas.bg.ac.rs 